\title{
Hospital Night Shift and Its Effects on the Quality of Sleep, the Quality of Life, and Vigilance Troubles among Nurses
}

\author{
Wided Boughattas ${ }^{1 *}$, Olfa El Maalel ${ }^{1}$, Ridha Ben Chikh², Maher Maoua', Kalboussi Houda', \\ Aicha Braham1 ${ }^{1}$, Houssem Rhif ${ }^{1}$, Souheil Chatti1, Faten Debbabi ${ }^{1}$, Mohamed Dogui ${ }^{2}$, \\ Nejib Mrizak1 \\ ${ }^{1}$ Occupational Medicine and Professional Pathologies Department, Medicine Faculty of Sousse, \\ Sousse, Tunisia \\ ${ }^{2}$ Neurophysiology Department, Sahloul Teaching Hospital, Sousse, Tunisia \\ Email: "boughattaswided@hotmail.fr
}

Received 10 March 2014; revised 8 April 2014; accepted 2 May 2014

Copyright (C) 2014 by authors and Scientific Research Publishing Inc.

This work is licensed under the Creative Commons Attribution International License (CC BY). http://creativecommons.org/licenses/by/4.0/

(c) (i) Open Access

\section{Abstract}

Introduction: The exposure to shift works, and especially to night shift, goes against the circadian rythmicity of the social man, which brings about a multitude of disruptive effects on health. In a hospital environment, such night shift is necessary so as to ensure the continuity of care. Sleep and vigilance disorders related to this work mode are frequent and often pose adaptation problems. The objective of this study is to detect the harmful effects of night shift on sleep, vigilance and the quality of life of nurses in Farhat Hached Teaching Hospital in Sousse. Material and Methods: It is a cross-sectional study carried out among two groups of nurses: one group performing a fixed night work and the other one working permanently during the day at Farhat Hached Teaching Hospital in Sousse. Data collection is mainly based on validated questionnaires evaluating sleep quality (Pittsburg sleep quality index), daytime sleepiness (Epworth sleepiness scale), sleep typology (Horne and Ostberg questionnaire), and the quality of life (SF-12). An objective evaluation of vigilance was realized by the study of reaction time and error rates to different tasks of "Super lab" software. Results: 50 night and 50 day nurses have been colligated. Both groups were age- and gender-matched. Sleep quality mean index was significantly higher among night nurses in comparison with day nurses $(10.2 \pm 5.9$ versus $6.76 \pm 5.16)$. After multivariate analysis, sleep quality was significantly correlated to age, department, schedule and the choice of schedule. Night shift was not related to daytime sleepiness. The objective analysis of vigilance showed that the reaction time to different tasks exploring the attentional mechanisms, as well as errors rate, were significantly more important among the night group. The mental score of the quality of life was significantly higher among day nurses. However, such difference was not significant with regard to

\footnotetext{
*Corresponding author.
} 
physical score. Conclusion: The findings of our study highlight not only the alteration of the health and the well being of paramedical staff secondary to night shift, but also a possible threat to safety care lavished by these teams, which involves the necessity to undertake preventive measures on an individual and collective scale.

\section{Keywords}

Night Shift, Nurse, Quality of Life, Sleep, Vigilance

\section{Introduction}

The development of socio-professional activities at night has gone hand in hand with the boom of artificial lighting which is characteristic of the modern world [1]. Currently, about one fifth of the working population is estimated to do a job during variable working times or at night when they more or less bear well [2].

In the health sector, night shift is particularly frequent [3]. Actually, the organization of hospital work must imperatively meet the demands of care continuity.

The psychological, relational and social repercussions of such schedule seem to be clear and are well demonstrated [4]. From $20 \%$ to $50 \%$ of night workers will stop their night professional activities due to these health problems [5]. Among the dramatic effects of night shift are sleep and vigilance disorders, the alteration of the mental health and the quality of life of the exposed person [6].

Among night workers, $60 \%$ complain of sleep disorders and 30\% of insomnia. Sleepiness affects $15 \%$ to $20 \%$ of them, with sleep being less restorative [7]. Unfortunately, sleep and vigilance disorders are very frequently underestimated in the workplace and remain part of the private life [8]. These vigilance disorders resulting from night shift are particularly dreadful, and engender an increased accidental risk [9] [10] which is all the more serious in care environment since it threatens not only the health of the concerned personnel, but also that of patients being cared for [11].

Although these various disorders are frequently reported by the night personnel of our hospitals, scarce are the studies which attempted to evaluate objectively the effects of such work rhythm on the workers' health.

The objective of our study was to detect the dramatic effects of night shift on sleep, vigilance, and the quality of life of nurses at Farhat Hached Teaching Hospital in Sousse (Tunisia).

\section{Material and Methods}

It is an epidemiological, cross-sectional of the type exposed - nonexposed study carried out during the second trimester of 2011 among nursing staff at Farhat Hached Teaching Hospital of Sousse.

\subsection{Subjects}

Voluntary nurses working permanently at night for more than 6 months were included in our study. Nurses working permanently during the day were age and gender-paired with the group of nurses exposed to night shift. Working hours were from 7:00 p.m. to 7:00 a.m. for night nurses and from 7:00 a.m. to 1:00 p.m. for day nurses.

The exclusion criteria were:

- Personal or family history of sleep disorder.

- Drug use that may interfere with sleep.

- Pregnant or breast-feeding women.

- Important visual disturbances.

- A second job.

\subsection{Procedure}

Data collection was realized by an objective test of vigilance performed for every nurse, and a questionnaire filled by the physician investigator while interviewing all participants in order to ensure a good comprehension of questions and to guarantee an answer to the entire questionnaire. The interview and the vigilance test as well were practiced during a rest break. 


\subsection{Measuring Instruments}

\section{1) Questionnaire}

The used questionnaire comprised 5 items:

- An item concerning the socio-professional and medical data.

- A second one exploring sleep quality using Pittsburg sleep quality index as

- A third item relative to the circadian typology of sleep where Horne and Ostberg questionnaire was used.

- A fourth one exploring vigilance using Epworth sleepiness scale.

- A fifth item related to the study of quality of life using SF-12 questionnaire in its French version.

\section{2) Objective test of vigilance}

During a rest break, an objective study of vigilance was carried out among both groups exposed and non-exposed to night shift using "Superlab" software, version 1.5.7. It is a program of exploration of the attentional abilities, based on the study of reaction time and the errors rate during the tasks execution included in this software. Three tasks were carried out: a task of simple reaction, a task of choice of positive subscripting, and a task of choice of negative subscripting. For every task, the subject sees a succession of items on the screen and is called to react as quickly as possible to a "target" by pressing the right button.

\subsection{Statistics}

Data entry and the analysis of results were realized using SPSS 11.0 software. We calculated the frequencies and percentages for the qualitative variables as well as the means, standard deviation, the medians and the extent of extreme values for the quantitative variables.

For the comparison of means, we used:

- Student's t-test for the comparison of two means of independent series.

- Snedecor's f-test of parametric variance analysis (one-way ANOVA) for the comparison of many means.

The comparison of frequencies was carried out using Pearson's chi-squared test.

For the multivariate study, we used:

1) A multiple linear regression when the dependent variable was quantitative.

2) And a multiple binary logistic regression when the dependent variable was qualitative.

The inclusion of independent variables in the regression models was done when their degree of significance was inferior to 0.2 . For all statistical tests, the significance level $\mathrm{p}$ was fixed at 0.05 .

\section{Results}

Only 50 night nurses accepted to take part in our survey i.e. a participation rate of $67 \%$. The average age of night nurses was $41.6 \pm 7.8$ years versus $40.2 \pm 8$ years for day nurses. In the night group, there was more man than in the day group. The consumption of stimulants was more important among night workers with a statistically significant difference regarding the smoking of water pipe $(p=0.006)$, the consumption of coffee $(p=$ $0.02)$ and alcohol $(p=0.007)$. Day nurses significantly exercised more extra-professional activities than night nurses $(\mathrm{p}=0.005)$.

Most of night and day nurses (26 versus 28 ) would be neutral. It should be noted that 9 morning subjects were working at night.

The average seniority in the current schedule was of $7.2 \pm 6.5$ years among day nurses versus $6.4 \pm 7.1$ years. There was no significant difference between both groups according to the departments they were appointed to. The rate of nurses having a professional upper-grade was higher among the day group. With regard to work accident, no significant difference was noted among both groups.

\section{Sleep Quality}

The overall score of Pittsburg sleep quality index (PSQI) was significantly higher among night workers (10.2 \pm 5.91 versus $6.76 \pm 5.16)(\mathrm{p}=0.02)$.

In the univariate analysis, sleep quality was significantly associated with age $(\mathrm{p}=0.03)$, family situation $(\mathrm{p}=$ $0.04)$, seniority $(p=0.02)$, unit of assignment $\left(p<10^{-3}\right)$, schedule $(p=0.003)$, schedule seniority $(p=0.001)$ and the choice of this latter $\left(p<10^{-3}\right)$ as well as the presence of another professional activity $(p=0.02)$.

After multivariate study, the factors determining sleep quality were age $\left(\mathrm{p}_{\mathrm{a}}=0.04\right)$, unit of assignment $\left(\mathrm{p}_{\mathrm{a}}=\right.$ 
$\left.10^{-3}\right)$, schedule $\left(\mathrm{p}_{\mathrm{a}}=0.05\right)$, choice of schedule $\left(\mathrm{p}_{\mathrm{a}}=0.002\right)($ Table 1 and Table 2$)$.

\section{Quality of Life}

The mental score of the quality of life was significantly included in the univariate analysis with gender $(\mathrm{p}=$ $0.01)$, sleep quality $(p=0.01)$, grade $(p=0.023)$, unit of appointment $(p=0.026)$, schedule $(p=0.005)$, and schedule seniority $(\mathrm{p}=0.013)$.

As for the physical score of the quality of life, it was significantly associated in the univariate analysis with BMI $(p=0.001)$, age $\left(p=10^{-3}\right)$, family situation $(p=0.027)$, the lowest age of children $(p=0.03)$, grade $(p=$ $\left.10^{-3}\right)$, seniority $\left(\mathrm{p}=10^{-3}\right)$, seniority in the unit $(\mathrm{p}=0.002)$, and in the schedule $(\mathrm{p}=0.036)$.

After linear regression, the mental score was significantly correlated with gender $\left(\mathrm{p}_{\mathrm{a}}=10^{-3}\right)$, the lowest age of children $\left(\mathrm{p}_{\mathrm{a}}=0.001\right)$, grade $\left(\mathrm{p}_{\mathrm{a}}=0.05\right)$, and schedule $\left(\mathrm{p}_{\mathrm{a}}=10^{-3}\right)$. Furthermore, the physical score was significantly correlated only with seniority $\left(\mathrm{p}_{\mathrm{a}}=10^{-3}\right.$ ) (Table 3 and Table 4).

Table 1. Sleep quality and extra-professional factors.

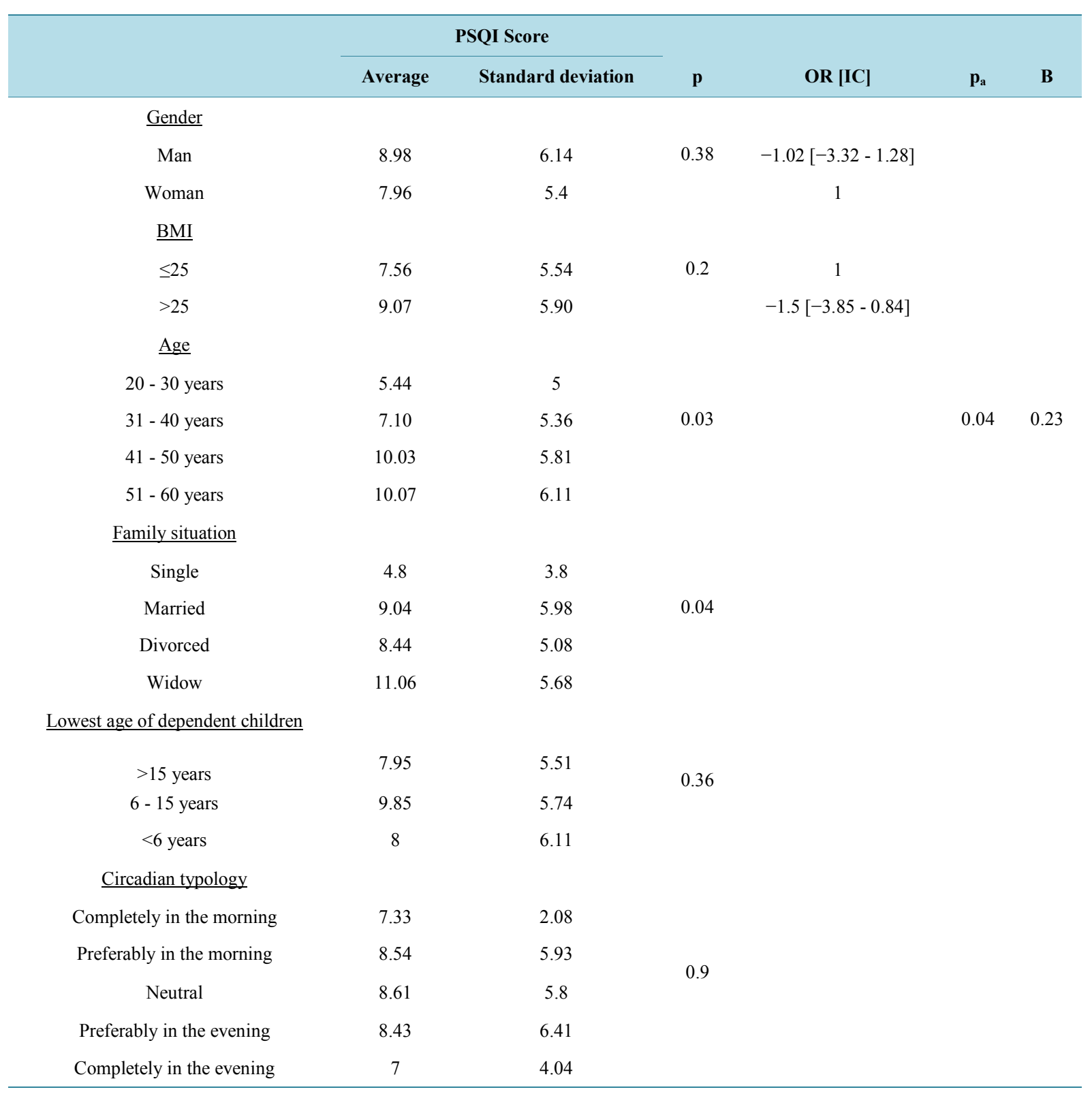


W. Boughattas et al.

Table 2. Sleep quality and professional factors.

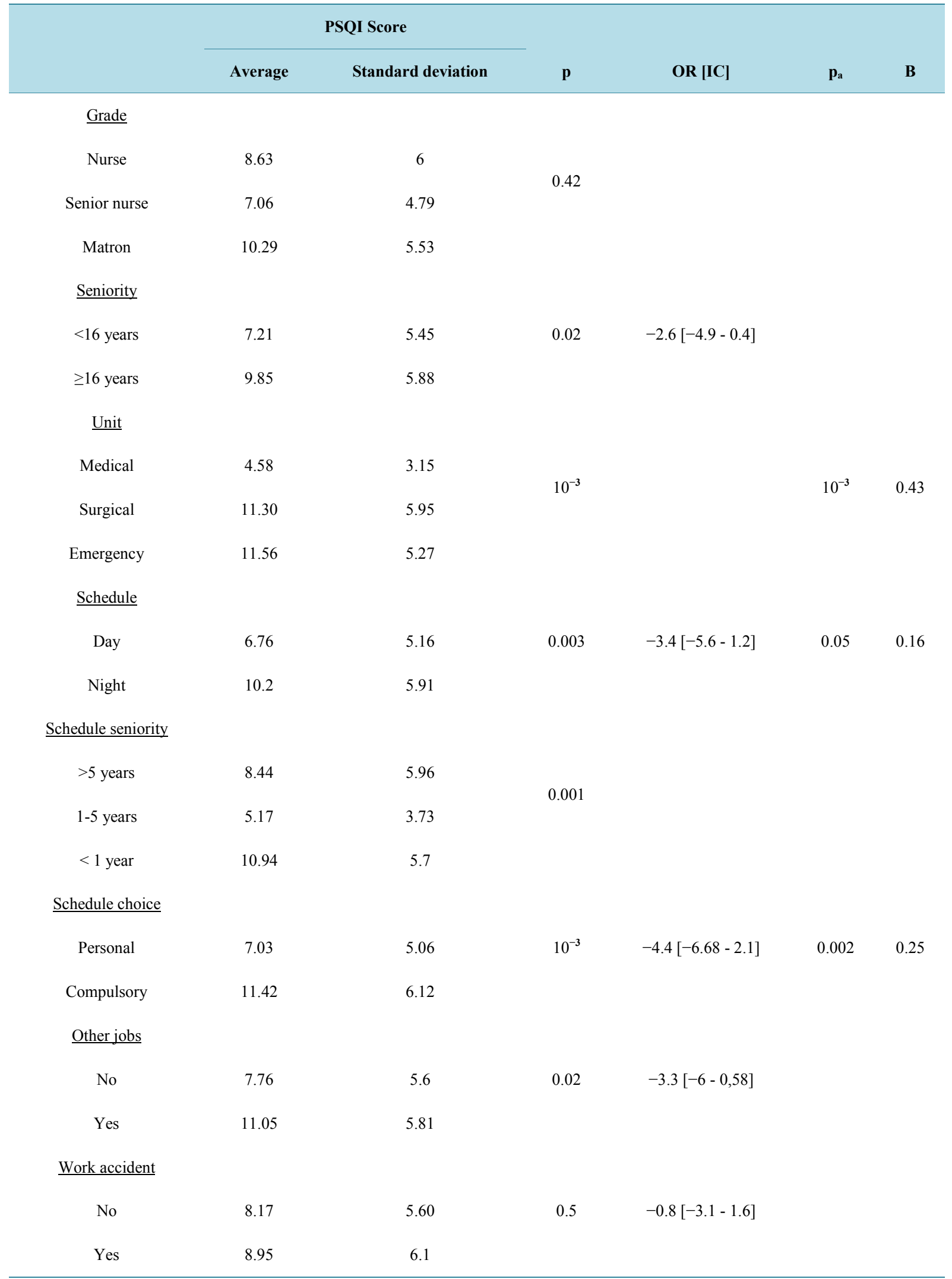


Table 3. Mental score and determining factors.

\begin{tabular}{|c|c|c|c|c|c|c|}
\hline & \multicolumn{2}{|c|}{ Mental Score } & \multirow[b]{2}{*}{$\mathbf{p}$} & \multirow[b]{2}{*}{ OR [IC] } & \multirow[b]{2}{*}{$\mathbf{p}_{\mathbf{a}}$} & \multirow[b]{2}{*}{ B } \\
\hline & Average & Standard deviation & & & & \\
\hline \multicolumn{7}{|l|}{$\underline{\text { Gender }}$} \\
\hline Woman & 36.71 & 7.05 & 0.01 & 1 & $10^{-3}$ & 0.41 \\
\hline Man & 41.06 & 9.59 & & $4.3[0.95-7.7]$ & & \\
\hline \multicolumn{7}{|l|}{ Lowest age } \\
\hline$>15$ years & 39.35 & 9.19 & \multirow{3}{*}{0.18} & & \multirow{3}{*}{0.001} & \multirow{3}{*}{0.33} \\
\hline $6-15$ years & 39.30 & 7.58 & & & & \\
\hline$<6$ years & 38.14 & 9.05 & & & & \\
\hline \multicolumn{7}{|l|}{$\underline{\text { Sleepquality }}$} \\
\hline Good & 40.87 & 7.82 & \multirow[t]{2}{*}{0.01} & 1 & & \\
\hline Bad & 36.65 & 9.16 & & $4.21[0.81-7.61]$ & & \\
\hline \multicolumn{7}{|l|}{$\underline{\text { Grade }}$} \\
\hline Nurse & 37.58 & 8.32 & \multirow{3}{*}{0.023} & & \multirow{3}{*}{0.05} & \multirow{3}{*}{-0.19} \\
\hline Senior nurse & 43.26 & 9.01 & & & & \\
\hline Matron & 42.76 & 8.10 & & & & \\
\hline \multicolumn{7}{|l|}{$\underline{\text { Unit }}$} \\
\hline Medical & 41.40 & 7.63 & \multirow{3}{*}{0.026} & & & \\
\hline Surgical & 35.84 & 7.77 & & & & \\
\hline Emergency & 38.41 & 10.17 & & & & \\
\hline \multicolumn{7}{|l|}{$\underline{\text { Schedule }}$} \\
\hline Day & 41.37 & 8.8 & \multirow[t]{2}{*}{0.005} & 1 & \multirow[t]{2}{*}{$10^{-3}$} & \multirow[t]{2}{*}{-0.38} \\
\hline Night & 36.49 & 7.91 & & $4.87[1.52-8.23]$ & & \\
\hline \multicolumn{7}{|c|}{ Schedule seniority } \\
\hline$>5$ years & 41.11 & 8.91 & \multirow{3}{*}{0.013} & & & \\
\hline $1-5$ years & 39.91 & 8.41 & & & & \\
\hline$<1$ year & 35.33 & 7.59 & & & & \\
\hline
\end{tabular}

\section{Vigilance}

\subsection{Daytime Sleepiness}

One fourth of night nurses versus one fifth of day nurses had daytime sleepiness according to Epworth scale with no statistically significant difference $(\mathrm{p}=0.47)$. However, Epworth sleepiness mean score was significantly higher $(\mathrm{p}=0.04)$ among the night group $(8 \pm 2.7$ among day nurses versus $9.1 \pm 2.5$ among night nurses $)$.

In the univariate analysis, daytime sleepiness was significantly associated with: BMI $(\mathrm{p}=0.01)$, age $(\mathrm{p}=$ $0.01)$, the occurrence of work accident $(\mathrm{p}=0.05)$.

After multivariate study, the factors which are significantly associated with daytime sleepiness were: gender $\left(\mathrm{p}_{\mathrm{a}}=0.007\right)$, age $\left(\mathrm{p}_{\mathrm{a}}=0.007\right)$, home-work daily journey $\left(\mathrm{p}_{\mathrm{a}}=0.01\right)($ Table 5$)$. 
Table 4. Physical score and determining factors.

\begin{tabular}{|c|c|c|c|c|c|c|}
\hline & \multicolumn{2}{|c|}{ Physical Score } & \multirow[b]{2}{*}{$\mathbf{p}$} & \multirow[b]{2}{*}{ OR $[\mathrm{IC}]$} & \multirow[b]{2}{*}{$\mathbf{p}_{\mathbf{a}}$} & \multirow[b]{2}{*}{ B } \\
\hline & Average & Standard deviation & & & & \\
\hline \multicolumn{7}{|l|}{ BMI } \\
\hline$\leq 25$ & 51.68 & 9.10 & 0.001 & 1 & & \\
\hline$>25$ & 43.60 & 12.28 & & $0.4[-3.2-3.9]$ & & \\
\hline \multicolumn{7}{|l|}{$\underline{\text { Age }}$} \\
\hline $20-30$ years & 53.84 & 7.73 & & & & \\
\hline $31-40$ years & 51.48 & 9.34 & $10^{-3}$ & & & \\
\hline $41-50$ years & 43.91 & 12.76 & & & & \\
\hline $51-60$ years & 37.23 & 8.95 & & & & \\
\hline \multicolumn{7}{|l|}{ Family situation } \\
\hline Single & 53.86 & 11.22 & & & & \\
\hline Married & 46.13 & 11.26 & 0.027 & & & \\
\hline Divorced & 44.64 & 13.36 & & & & \\
\hline Widow & 37.56 & 10.24 & & & & \\
\hline \multicolumn{7}{|l|}{ Lowest age } \\
\hline$>15$ years & 46.81 & 12.19 & \multirow{3}{*}{0.03} & & & \\
\hline $6-15$ years & 42.30 & 11.32 & & & & \\
\hline$<6$ years & 50.15 & 10.80 & & & & \\
\hline \multicolumn{7}{|l|}{$\underline{\text { Grade }}$} \\
\hline Nurse & 49.30 & 10.98 & \multirow{3}{*}{$10^{-3}$} & & & \\
\hline Senior nurse & 39.57 & 11.18 & & & & \\
\hline Matron & 37.03 & 10.46 & & & & \\
\hline \multicolumn{7}{|l|}{$\underline{\text { Seniority }}$} \\
\hline$<16$ years & 51,72 & 9.03 & \multirow[t]{2}{*}{$10^{-3}$} & & $10^{-3}$ & -0.44 \\
\hline$\geq 16$ years & 41.34 & 12.13 & & & & \\
\hline \multicolumn{7}{|c|}{ Seniority in the unit } \\
\hline$<10$ years & 50.35 & 10.42 & \multirow[t]{2}{*}{0.002} & & & \\
\hline$\geq 10$ years & 42.97 & 12.05 & & & & \\
\hline \multicolumn{7}{|c|}{$\underline{\text { Schedule seniority }}$} \\
\hline$>5$ years & 44.01 & 11.25 & \multirow{2}{*}{0.036} & & & \\
\hline $1-5$ years & 45.83 & 13.51 & & & & \\
\hline$<1$ year & 50.99 & 10.13 & & & & \\
\hline
\end{tabular}


Table 5. Daytime sleepiness and determining factors.

\begin{tabular}{|c|c|c|c|c|c|c|}
\hline Variables & Somnolents (\%) & Nonsomnolents (\%) & $\mathrm{p}$ & OR & $\mathrm{p}_{\mathrm{a}}$ & ORa \\
\hline \multicolumn{7}{|l|}{ Gender } \\
\hline Woman & 65.2 & 44.2 & 0.07 & 1 & 0.007 & 1 \\
\hline Man & 34.8 & 55.8 & & $0.4[0.2-1.1]$ & & $0.2[0.1-0.7]$ \\
\hline \multicolumn{7}{|l|}{ Age } \\
\hline $20-30$ & 0 & 11.7 & & 1 & & 1 \\
\hline $31-40$ & 30.4 & 41.6 & 0.01 & $1.1[0.4-3.2]$ & 0.007 & $0.9[0-1.7]$ \\
\hline $41-50$ & 43.5 & 35.1 & & $3.5[1.2-9.7]$ & & $1.1[1.1-4.9]$ \\
\hline $51-60$ & 26.1 & 11.7 & & $6[0.34-12.4]$ & & $2.3[1.1-8.2]$ \\
\hline \multicolumn{7}{|l|}{ BMI } \\
\hline$<25$ & 17.4 & 45.5 & 0.01 & 1 & & \\
\hline$\geq 25$ & 82.6 & 54.5 & & $3.96[1.2-12.7]$ & & \\
\hline \multicolumn{7}{|c|}{ Home-work journey } \\
\hline$<10 \mathrm{Km}$ & 47.8 & 68.8 & & 1 & & 1 \\
\hline$>10 \mathrm{Km}$ & 52.2 & 31.2 & 0.06 & $2.4[0.9-6.2]$ & 0,01 & $3.6[1.2-11.2]$ \\
\hline \multicolumn{7}{|c|}{ Work accident } \\
\hline Yes & 43.5 & 64.9 & & 1 & & \\
\hline No & 56.5 & 35.1 & 0.05 & $2.41[0.9-6.2]$ & & \\
\hline
\end{tabular}

\subsection{Objective Test of Vigilance}

The objective evaluation of vigilance showed that the mean time of reaction to different tasks exploring attentional mechanisms as well as the errors rate were significantly more important among the night group (Figure 1 and Table 6).

\section{Discussion}

\subsection{Sleep Quality}

Sleep is the main function disturbed by night shift [8]. There is reduction of sleep duration among night workers because of the obligation to sleep during the usual early hours, especially when the surrounding conditions are unfavorable (light, noise, temperature) [12].

In our study, sleep quality was evaluated by the overall score of Pittsburg sleep quality index (PSQI). PSQI is known to evaluate sleep quality during the month preceding the study. It was used in many other surveys [13] [14].

Night shift was found to affect significantly sleep quality. The dramatic effect of such atypical schedule was widely discussed in the literature. Our results are similar to those of Rutenfranz J. et al. [15] who found that almost $70 \%$ of night workers complain of sleep disorders, assessing their sleep as insufficient, unsatisfactory and little restorative.

According to Akersted T. [12], sleep duration is reduced to 2 - $4 \mathrm{~h}$ after a working night; light and REM sleep seem to be the phases most affected. Night workers' most reported subjective complaints are early morning waking and the sensation of unrefreshing sleep. Estryn-Behar M. et al. [16] noticed that in fixed overnight, $60 \%$ of nurses sleep $6 \mathrm{~h}$ or less. It seems, actually, that shift work, and mainly night work, leads to a decrease in sleep quality and quantity [17] [18].

In our survey, age was identified as a factor influencing sleep quality. In fact, this result is expected in the literature [1] [19]-[21]; the effect of age on sleep quality was widely reported. In a meta-analysis of 65 articles which evaluates objectively (polysomnography or actigraphy) sleep quality of 3577 healthy subjects, Ohayon M.M. etal. [19] brought to light a decrease with age of the different qualitative and quantitative parameters of sleep. Such progressive intolerance to night work associated with aging can be accounted for by a decrease of the 


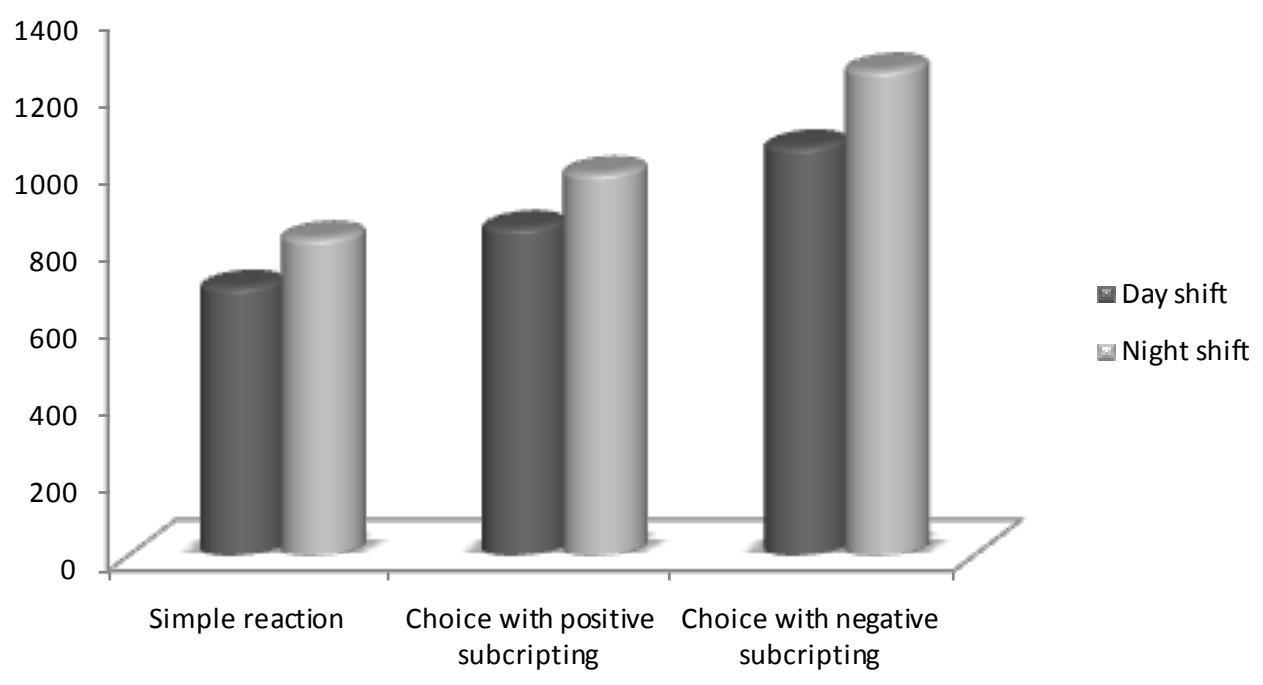

Figure 1. Distribution according to time of reaction to tasks: of simple reaction (1), of choice with positive subscripting (2), of choice with negative subscripting (3).

Table 6. Percentages of overall errors among both groups in terms of task function.

\begin{tabular}{cccc}
\hline & Exposed (\%) & Nonexposed (\%) & p \\
\hline Task of simple reaction & & & \\
Average & 23.8 & 17.2 & 0.03 \\
Standard deviation & 16.52 & 13.48 & \\
Task of absolute subscripting & & & $10^{-3}$ \\
Average & 26.28 & 16.46 & \\
Standard deviation & 16.38 & 11.03 & 0.04 \\
Location task & & & \\
Average & 15.12 & 8.68 & \\
Standard deviation & 12.19 & & \\
\hline
\end{tabular}

psycho-physical adaptation of the individual and a greater predisposition to the desynchronization of the circadian rhythm among elder subjects [1].

We have noticed that single persons enjoy a better quality of sleep. In the literature, the results concerning marital status are contradictory. Actually, in a study carried out among 418 Turkish nurses about sleep quality, using PSQI as tool of investigation, Karagozoglu S. and Bingöl [22] brought into light a better sleep quality among married nurses. Contrary to that, in a study conducted by Vidacek S. et al. [23], we find that after a working night, married women sleep less well than single women.

According to the results of our survey, some professional factors such as unit of appointment and schedule choice affect sleep quality.

Nurses working in the intensive care unit and the emergency department had poor sleep quality compared to those working in the surgical wards who themselves sleep less well than nurses in medical wards. This can be explained by a more important workload in intensive care and surgery which would affect negatively sleep quality by increasing stress level. These same results were confirmed by Karagozoglu S. and Bingöl N. [22].

\subsection{Quality of Life}

There are many studies about the impact of night shift on the quality of life. We have chosen as a measuring instrument the SF-12 which is a tool widely used in sick populations as well as in healthy populations. The univariate approach of the impact of night shift on the quality of life seems to indicate in our survey a better quality of psychological life among nurses working during the day with regard to those working at night as had been iden- 
tified by other studies [24]-[29]. However, given the multiplicity and numerousness of the factors influencing the quality of life, a multivariate approach is imperative in order to gather information more precisely on the real role of the schedule type. The adjustment with other variables (socio-demographic criteria, sleep quality, other professional characteristics) showed that the physical component of the quality of life was not dependent on night shift, but rather on seniority, and only the mental component was correlated with the fixed overnight schedule. This significant correlation was negative and strong. This is probably related to an isolation which is at the same time social and professional linked with night shift.

\subsection{Vigilance}

In our study, the vigilance of the inquired nurses was evaluated via two methods: a subjective one consisting in the evaluation of daytime sleepiness using Epworth sleepiness scale, and an objective exploration of the attention during work based on tasks of reaction time, and constructed with the help of "Superlab" software.

After adjustment with all the confounding factors, our results indicate that daytime sleepiness is significantly associated with gender, age and home-work daily journey.

We noticed that women complain more of daytime sleepiness, and as such: $65.2 \%$ of nurses presenting with a daytime sleepiness were women. Kim H. and Young T.'s study about 2913 persons in general population confirmed that the female gender expresses more frequently the feeling of sleepiness and the propensity of sleep [30]. However, in Sleep Heart Health study researching for the association between gender and daytime sleepiness, Baldwin C. et al. [31] concluded that although women report more a feeling of sleepiness, they were objectively less somnolent than men when faced with active situations.

Age was isolated as an independent factor influencing daytime sleepiness in our study. Actually, the age group ranging from 51 to 60 years had 2.35 times more risks of having a daytime sleepiness than the age group ranging from 20 to 30 years. This age effect was highlighted by many authors [30] [32]-[34]. However, in the literature, the results are contradictory. Our results were in harmony with those of Bixler E.O. et al. [35] who, in an epidemiological study about 16,583 subjects in general population, showed a positive relationship between old age and sleepiness.

The objective evaluation by the test of reaction time and the errors rate brought into light the dramatic effects of night shift on the vigilance of our nurses. For many decades, performance deteriorations during night shift were highlighted [36]-[38]. Many surveys based on the study of tests of vigilance and the tasks of reaction time [39]-[44] indicated that most of the activities necessitating close attention would be reduced after a night shift. In parallel with our results, in a study based on a battery of neuro-psychological tests at the beginning and at the end of the shift, about interns working the emergency department, Rollinson D. et al. [45] could objectivize an ability deterioration of the visual memory during night shift. Similar results were reported by two studies of Smith-Coggins R. et al. [46] [47] who showed a slowdown of physicians working at night to perform an intubation simulation test with regard to the day group.

Sleep and vigilance disorders are still unrecognized in Occupational Medicine. These troubles are susceptible to change the quality of life and the dispensing of patients care in hospital, and to pose problems of capacity for shift work. Caring for workers exposed to atypical scheduled work, and apart from the consequences that this latter brings about, must be multidisciplinary. The attention of occupational health doctor would be devoted not only to the early detection of sleep disorders, but also to the research for occupational or traffic accidents possibly related to hypo-vigilance, and to the good determination of the exposed personnel's aptitude.

\section{References}

[1] Costa, G. (2003) Shift Work and Occupational Medicine: An Overview. Occupational Medicine, 53, 83-88. http://dx.doi.org/10.1093/occmed/kqg045

[2] Léger, D. and Guilleminault, C. (1997) Sommeil, Vigilance et Travail. Masson, Paris, 176 p.

[3] Dorrian, J., Tolley, C., Lamond, N., Van Den Heuvel, C., Pincombe, J., Rogers, A.E., et al. (2008) Sleep and Errors in a Group of Australian Hospital Nurses at Work and during the Commute. Applied Ergonomics, 39, 605-613. http://dx.doi.org/10.1016/j.apergo.2008.01.012

[4] Driscoll, T.R., Grunstein, R.R. and Rogers, N.L. (2007) A Systematic Review of the Neurobehavioural and Physiological Effects of Shiftwork Systems. Sleep Medicine Reviews, 11, 179-194. http://dx.doi.org/10.1016/j.smrv.2006.11.001

[5] Costa, G. (1997) The Problem: Shiftwork. Chronobiology International, 14, 89-98. 
http://dx.doi.org/10.3109/07420529709001147

[6] Åkerstedt, T. (2007) Altered Sleep/Wake Patterns and Mental Performance. Physiology \& Behavior, 90, 209-218. http://dx.doi.org/10.1016/j.physbeh.2006.09.007

[7] Lubin, S. and Prévot, E. (2006) Bilan de sommeil en médecine du travail. Médecine du Sommeil, 3, 47-53. http://dx.doi.org/10.1016/S1769-4493(06)70068-1

[8] Léger, D., Bayon, V., Metlaine, A., Prevot, E., Didier-Marsac, C. and Choudat, D. (2009) Horloge Biologique, Sommeil et conséquences médicales du travail posté. Archives des Maladies Professionnelles et de l'Environnement, 70, 246-252. http://dx.doi.org/10.1016/j.admp.2009.01.007

[9] Gold, D.R., Rogacz, S., Bock, N., Tosteson, T.R., Baum, T.M., Speizerand, F.E. and Czeisler, C.A. (1992) Rotating Shift Work, Sleep, and Accidents Related to Sleepiness in Hospital Nurses. American Journal of Public Health, 82, 1011-1014. http://dx.doi.org/10.2105/AJPH.82.7.1011

[10] Olson, E.J., Drage, L.A. and Augerand, R. (2009) Patient Safety Sleep Deprivation, Physician Performance. Chest Journal, 136, 1389-1396. http://dx.doi.org/10.1378/chest.08-1952

[11] Suzuku, K., Ohida, T., Kaneita, Y., Yokoyama, E., Miyake, T., Harano, S., Yagi, Y., Ibuka, E., Kaneko, A., Tsutsui, T. and Ushiyama, M. (2004) Mental Health Status, Shift Work, and Occupational Accidents among Hospital Nurses in Japan. Journal of Occupational Health, 46, 448-454. http://dx.doi.org/10.1539/joh.46.448

[12] Akerstedt, T. (2003) Shift Work and Disturbed Sleep/Wakefulness. Occupational Medicine, 53, 89-94. http://dx.doi.org/10.1093/occmed/kqg046

[13] Souza, J.C., Paiva, T. and Reimao, R. (2005) Sleep Habits, Sleepiness and Accidents among Truck Drivers. Arquivos de Neuro-Psiquiatria, 63, 925-930. http://dx.doi.org/10.1590/S0004-282X2005000600004

[14] Johnson, D.A., Orr, W.C., Crawley, J.A., et al. (2005) Effect of Esomeprazole on Nighttime Heartburn and Sleep Quality in Patients with GERD: A Randomized, Placebo-Controlled Trial. The American Journal of Gastroenterology, 100, 1914-1922. http://dx.doi.org/10.1111/j.1572-0241.2005.00285.x

[15] Rutenfranz, J., Haider, M. and Koller, M. (1985) Occupational Health Measures for Nightworkers and Shiftworkers. In: Folkard, S. and Monk, T.H., Eds., Hours of Work: Temporal Factors in Work Scheduling, John Wiley \& Sons, New York, 199-210.

[16] Estryn-Behar, M., Gadbois, C. and Vaichere, E. (1978) Effets du travail de nuit en équipes fixes sur une population féminine. Résultats d'une enquête dans le secteur hospitalier. Archives des Maladies Profissionelles de Médecine du Travail et de Sécurité Sociale, 39, 531-535.

[17] Härmä, M., Tenkanen, L., Sjöblom, T., Alikoski, T. and Heinsalmi, P. (1998) Combined Effects of Shift Work and Life Style on the Prevalence of Insomnia, Sleep Deprivation and Daytime Sleepiness. Scandinavian Journal of Work, Environment \& Health, 24, 300-307. http://dx.doi.org/10.5271/sjweh.324

[18] Ohayon, M.M., Lemoine, P., Arnaud-Briant, V. and Dreyfus, M. (2002) Prevalence and Consequences of Sleep Disorders in a Shift Worker Population. Journal of Psychosomatic Research, 53, 577-583. http://dx.doi.org/10.1016/S0022-3999(02)00438-5

[19] Ohayon, M.M., Carskadon, M.A., Guilleminault, C. and Vitiello, M.V. (2004) Metaanalysis of Quantitative Sleep Parameters from Childhood to Old Age in Healthy Individuals: Developing Normative Sleep Values across the Human Lifespan. Sleep, 27, 1255-1273.

[20] Silva, G.E., Goodwin, J.L., Sherrill, D.L., Arnold, J.L., Bootzin, R.R., Smith, T., et al. (2007) Relationship between Reported and Measured Sleep Times: The Sleep Heart Health Study (SHHS). Journal of Clinical Sleep Medicine, 3, $622-630$.

[21] Deriennic, F., Ribet, C. and Volkoff, S. (1999) Les troubles du sommeil, l'âge et le travail. DARES, 23, 1-6.

[22] Karagozoglu, S. and Bingöl, N. (2008) Sleep Quality and Job Satisfaction of Turkish Nurses. Nursing Outlook, 56, 298-307. http://dx.doi.org/10.1016/j.outlook.2008.03.009

[23] Vidacek, S., Radosevic-Vidacek, B., Kaliterna, L. and Prizmic, Z. (1990) The Productivity of Female Shift Workers. Archives of Industrial Hygiene and Toxicology, 41, 339-345.

[24] Adam, A., Courthiat, M.-C., Vespignani, H., Emser, W. and Hannarth, B. (2007) Effets des horaires de travail posté et de nuit sur la qualité du sommeil, la vigilance et la qualité de vie: Etude interrégionale franco-allemande. Archives des Maladies Professionnelles et de l'Environnement, 68, 482-493. http://dx.doi.org/10.1016/S1775-8785(07)78219-X

[25] Kaliterna Lipovcan, L.J., Prizmic Larsen, Z. and Zganec, N. (2004) Quality of Life, Life Satisfaction and Happiness in Shift and Non-Shiftworkers. Revista de Saúde Pública, 38, 3-10. http://dx.doi.org/10.1590/S0034-89102004000700002

[26] Tepas, D.I., Barnes-Farrell, J.L., Bobko, N., Fisher, F.M., Iskra-Golec, I. and Kaliterna, L. (2004) The Impact of Night Work on Subjective Reports of Well-Being: An Exploratory Study of Health Care Workers from Five Nations. Revista de Saúde Pública, 38, 26-31. http://dx.doi.org/10.1590/S0034-89102004000700005 
[27] Suzuku, K., Ohida, T., Kaneita, Y., Yokoyama, E., Miyake, T., Harano, S., Yagi, Y., Ibuka, E., Kaneko, A., Tsutsui, T. and Ushiyama, M. (2004) Mental Health Status, Shift Work, and Occupational Accidents among Hospital Nurses in Japan. Journal of Occupational Health, 46, 448-454. http://dx.doi.org/10.1539/joh.46.448

[28] Mori, T. and Kageyama, T. (1995) A Cross-Sectional Survey on Mental Health and Working Environment of Hospital Nurses. Journal of Occupational Health, 37, 123-134.

[29] Bohle, P. and Tilley, A.J. (1998) Early Experience of Shiftwork: Influences on Attitudes. Journal of Occupational and Organizational Psychology, 71, 61-70. http://dx.doi.org/10.1111/j.2044-8325.1998.tb00663.x

[30] Kim, H. and Young, T. (2005) Subjective Daytime Sleepiness: Dimensions and Correlates in the General Population. Sleep, 28, 625-634.

[31] Baldwin, C., Kapur, V., Holberg, C., Rosen, C. and Nieto, J. (2004) Associations between Gender and Measures of Daytime Somnolence in the Sleep Heart Health Study. Sleep, 27, 305-311.

[32] Lindberg, E., Janson, C., Gislason, T., Björnsson, E., Hetta, J. and Boman, G. (1997) Sleep Disturbances in a Young Adult's Population: Can Gender Differences Be Explained by Differences in Psychological Status. Sleep, 20, 381-387.

[33] Yoon, I.Y., Kripke, D.F., Elliot, J.A., Youngstedt, S.D., Rex, K.M. and Hauger, R.L. (2003) Age-Related Changes of Circadian Rhythms and Sleep-Wake Cycles. Journal of the American Geriatrics Society, 51, 1085-1091. http://dx.doi.org/10.1046/j.1532-5415.2003.51356.x

[34] Ancoli-Israel, S., Poceta, J.S., Stepnowsky, C., Martin, J. and Gehrman, P. (1997) Identification and Treatment of S1eep Problems in the Elderly. Sleep Medicine Reviews, 1, 3-17. http://dx.doi.org/10.1016/S1087-0792(97)90002-2

[35] Bixler, E.O., Vgonezas, A.N., Lin, H.M., Calhoun, S.L., Vela-Bueno, A. and Kales, A. (2005) Excessive Daytime Sleepiness in a General Population Sample: The Role of Sleep Apnea, Age, Obesity Diabetes and Depression. The Journal of Clinical Endocrinology \& Metabolism, 90, 4510-4515. http://dx.doi.org/10.1210/jc.2005-0035

[36] Folkard, S. (1981) Shiftwork and Performance. In: Johnson, L.C., Tepas, D.I., Colquehoun, W.P. and Colligan, M.J., Eds., Biological Rhythms, Sleep and Shiftwork, Advances in Sleep Research, 283-305.

[37] Folkard, S. and Monk, T. (1979) Shiftwork and Performance. Human Factors, 21, 483-492.

[38] Son, M., Kong, J.-O., Koh, S.-B., Kim, Y. and Härmä, M. (2008) Effects of Long Working Hours and the Night Shift on Severe Sleepiness among Workers with 12 Hour Shift Systems for 5 to 7 Consecutive Days in the Automobile Factories of Korea. Journal of Sleep Research, 17, 385-394. http://dx.doi.org/10.1111/j.1365-2869.2008.00675.x

[39] Akerstedt, T., Peters, B., Anund, A. and Kecklund, G. (2005) Impaired Alertness and Performance Driving Home from the Night Shift: A Driving Simulator Study. Journal of Sleep Research, 14, 17-20. http://dx.doi.org/10.1111/j.1365-2869.2004.00437.x

[40] Fröberg, J., Karlsson, C.G., Levi, L. and Lidberg, L. (1975) Circadien Variations of Cathecholamine Excretion, Shooting Range Performance and Self-Ratings of Fatigue During Sleep Deprivation. Biological Psychology, 2, 175-188. http://dx.doi.org/10.1016/0301-0511(75)90018-6

[41] Gillberg, M., Kecklund, G. and Akerstedt, T. (1996) Sleepiness and Performance of Professional Drivers in a Truck Simulator: Comparison between Day and Night Driving. Journal of Sleep Research, 5, 12-15. http://dx.doi.org/10.1046/j.1365-2869.1996.00013.x

[42] Gillberg, M., Kecklund, G., Göransson, B. and Akerstedt, T. (2003) Operator Performance and Signs of Sleepiness during Day and Night Work in a Simulated Thermal Power Plant. International Journal of Industrial Ergonomics, 31, 101-109. http://dx.doi.org/10.1016/S0169-8141(02)00178-6

[43] Lamond, N., Dorrian, J., Roach, G.D., McCulloch, K., Holmes, A.L., Burgess, H.J., Fletsher, A. and Dawson, D. (2003) The Impact of a Week of Simulated Night Work on Sleep, Circadian Phase and Performance. Occupational and Environmental Medicine, 60, e13. http://dx.doi.org/10.1136/oem.60.11.e13

[44] Hossain, J.L., Reinish, L.W., Heslegrave, R.J., Hall, G.W., Kayumov, L., Chung, S.A., Bhuiya, P., Jovanovic, D., Huterer, N., Volkov, J. and Shapiro, C.M. (2004) Subjective and Objective Evaluation of Sleep and Performance in Daytime versus Nighttime Sleep in Extended-Hours Shift-Workers at an Underground Mine. Journal of Occupational and Environmental Medicine, 46, 212-226. http://dx.doi.org/10.1097/01.jom.0000117421.95392.31

[45] Rollinson, D.C., Rathlev, N.K., Moss, M., Killiany, R., Sassower, K.C., Auerbach, S. and Fish, S. (2003) The Effects of Consecutive Night Shifts on Neuropsychological Performance of Interns in the Emergency Department: A Pilot Study. Annals of Emergency Medicine, 41, 400-406. http://dx.doi.org/10.1067/mem.2003.77

[46] Smith-Coggins, R., Rosekind, M.R., Hurd, S. and Buccino, K.R. (1994) Relationship of Day versus Night Sleep to Physician Performance and Mood. Annals of Emergency Medicine, 24, 928-934. http://dx.doi.org/10.1016/S0196-0644(94)70209-8

[47] Smith-Coggins, R., Rosekind, M.R. and Buccino, K.R. (1997) Rotating Shiftwork Schedules: Can We Enhance Physician Adaptation to Night Shifts? Academic Emergency Medicine, 4, 951-961. http://dx.doi.org/10.1111/j.1553-2712.1997.tb03658.x 